\title{
SOLID WASTES CONVERSION INTO ELECTRIC AND THERMAL ENERGY USING A GASIFIER AND AN ELECTROCHEMICAL GENERATOR
}

\author{
SERGEY E. SHCHEKLEIN \& ALEXEY M. DUBININ \\ First President of Russia B.N. Yeltsyn Ural Federal University, Russia
}

\begin{abstract}
In Russia, 3.4 billion tons of municipal solid wastes (SW) are accumulated annually. Over 40 thousand hectares of fertile lands have been used for solid waste disposal; and the areas to be disposed each year for the SW landfills amount to as much as three thousand hectares. This work presents calculation results are reported from the study of a power plant based on the solid oxide fuel cells (SOFCs), which utilizes as fuel the synthesis gas generated through the SW steam gasification in an autothermal gasifier. Solid oxide fuel cells (SOFCs) are the most convenient for such a combined system, as due to high operating temperatures they do not require high fuel quality. The calculations have demonstrated the following: the temperature in the reaction vessel of the gasifier is at $1,000^{\circ} \mathrm{C}$, the synthesis gas output is $55 \mathrm{~m}^{3} / \mathrm{h}$, the chemical efficiency is $35.4 \%$, and the synthesis gas combustion heat is $1.6352 \mathrm{~kJ} / \mathrm{kg}$ of synthesis gas. The electric power electrochemical generator is $97.86 \mathrm{~kW}$, the (total) electric efficiency of electrochemical generator is $39.1 \%$, the temperature of gases effluent from the boiler-utilizer is at $630^{\circ} \mathrm{C}$. Theorized the possibility of solid waste into electrical and thermal energy with full efficiency more than $79 \%$.

Keywords: autothermal steam gasification, domestic solid wastes, electrochemical generator, hydrogen fraction, EMF, (total) efficiency, temperature, stoichiometry, solid oxide fuel cells (SOFC), power, heat.
\end{abstract}

\section{INTRODUCTION}

In Russia, 3.4 billion tons of municipal solid wastes (SW) are accumulated annually. Over 40 thousand hectares of fertile lands have been used for solid waste disposal; and the areas to be disposed each year for the SW landfills amount to as much as three thousand hectares.

SW to be dumped into the landfills comprise (percent by weight): paper and cardboard $(30 \%)$; plastic (5\%); textile $(6 \%)$; rubber and skin $(3 \%)$; wood $(4 \%)$; food waste $(22 \%)$; other $(30 \%)$. One household would routinely generate $225 \mathrm{~kg}$ of SW to be dumped in the landfills each year.

Solid wastes are commonly known to be divided into medical, biological, constructional, transport-related, agricultural, and industrial wastes.

To utilize medical and biological wastes, incinerators are known to be used. They may reach $270 \mathrm{~kg} / \mathrm{h}$ in capacity; and due to a high temperature $\left(1,000^{\circ} \mathrm{C}\right)$, toxic and pathogenic agents are eliminated. As of today, SW utilization in Russia to yield energy is used to one per cent of the possible capacity only. As a rule, $96.5 \%$ of SW is disposed in the landfills, which are prone to be bleeding gaseous products containing carbon oxide, ammonium, and hydrogen sulfide. In this paper, calculations are reported from the research on the SW converting into electric and thermal energy using a solid oxide fuel cell-based electrochemical generator and an auto thermal gasifier for carrying out SW steam reforming.

Solid oxide fuel cells (SOFCs) appear to be most convenient for the purpose, because they use air as oxidant and the synthesis gas, resulted from SW steam reforming, as fuel. Solid oxide fuel cells (SOFCs) are the most convenient for such a combined system, as due to high operating temperatures they do not require high fuel quality [1]. The electrochemical generator uses SOFCs of flat plane design with the direct flow of fuel and oxidant, with the 
catalysts made of NiYSZ in the anode, cathode and electrolyte between them of $\left(\mathrm{ZrO}_{2}\right)_{0.9}$ $\left(\mathrm{SC}_{2} \mathrm{O}\right)_{0.1}$ [2]. In recent years, actively developed new methods of solid waste management using modern solid electrochemical generators in combination with Stirling engines and gas turbines [3]-[5].

The study [6], offers over 220 versions of calculated SOFCs according to two arrangements: one involving anode gases recirculation and the other without it. A conclusion is made that so much the simpler the arrangement, so much the better.

A technique that we have developed allows predicting for the process parameters: the temperature in the reaction vessel of auto thermal gasifier for SW converting into synthesis gas; the temperature at the SOFC anode; the (total) electric efficiency of the electrochemical generator (ECG); the fraction of hydrogen oxidized on the anode; the specific consumption rates of SW for producing electric and thermal energies; the losses in the ECG with effluent gases and into the environment.

\section{SCHEMATIC OF GASIFIER AND ECG-BASED HEAT AND POWER PLANT}

Fig. 1. A schematic of the gasifier and ECG-based HPP for converting solid wastes (SW) into electric and thermal energy:

1 - gasifier; 2 - cyclone for synthesis gas; 3 - cyclone for synthesis gas combustion products; 4 - mechanical filter for synthesis gas; 5 -synthesis gas cooler; 6 - synthesis gas scrubber; 7 - mechanical filter for synthesis gas combustion products; 8 - synthesis gas heater; 9 - synthesis gas combustion products utilizer; 10- flat plate SOFC-based ECG; 11- boilerutilizer; 12 - network heater. I - TDW input; II - air inlet; Ш - chemically cleaned deaired water inlet; IV - effluent gases outlet; V - electric energy output; VI - ashes removal.

The synthesis gas was produced using a fluidized-bed gasifier with a layer of fused alumina of $0.32 \mathrm{~mm}$-sized particles to auto thermal oxygen-free steam reforming of SW (1). Fig. 2 displays a detailed description of such gasifier.

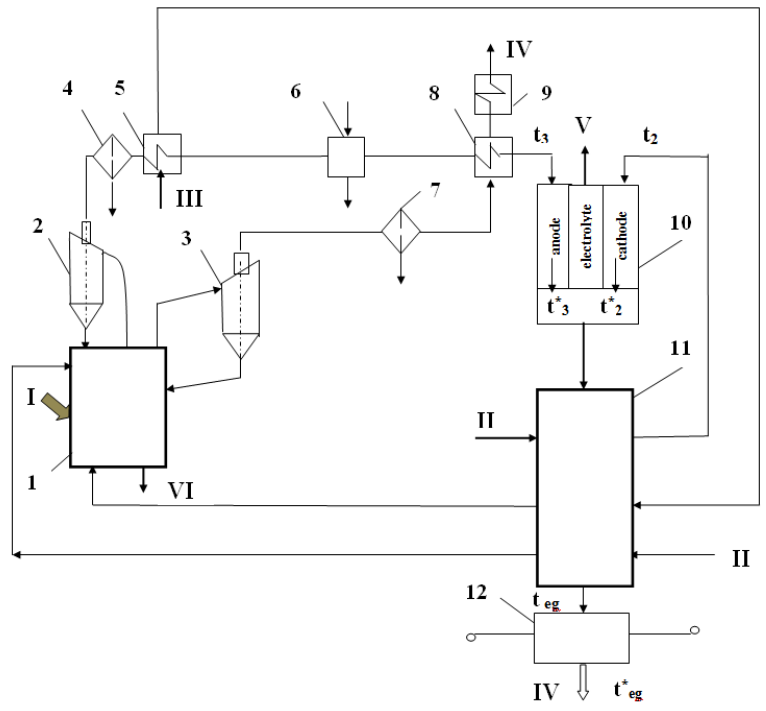

Figure 1: The HPP schematic. 
Superheated steam from the BU is fed into a cap steam distribution grate of the gasifier. To ensure the auto thermal process and to provide heating of the gasification products up to $1,000^{\circ} \mathrm{C}$, which eliminates toxic and pathogenic agents, a combustion chamber is designed, where synthesis gas gets partially oxidized. The thermal power thus generated is transferred into the reaction vessel through intermixing the dispersed particles of fused alumina; with synthesis gas being removed via the central pipe separately from the consumption products. Domestic solid wastes are fed in the same direction with the air, similar to the way it is done in the downdraft gasification system, when dry-run products are passing the burning zone and decompose, which makes it possible to eliminate $94 \%$ of phenols, toxins, and pathogens [7]. In the fluidized-bed, the solid phase (fused alumina) mixes well, unlike the gaseous phase which mixes poorly. Therefore, to ensure better mixing of the synthesis gas and air, a peak 11 is provided (see Fig. 2). Thus, a uniform temperature is maintained throughout the entire fluidized bed.

Fig. 2, Gasifier system for auto thermal steam gasification of domestic solid wastes (SW). 1 - cap steam distribution grate; 2 - boiler; 3 -fluidized bed of fused alumina; 4 - thermal insulation; 5 - lock feeder; 6 - gate valve; 7 - SW hopper; 8 - central pipe for removing synthesis gas; 9 - connecting pipe for removing completely burnt synthesis gas combustion products; 10 - pipe for ash removal; 11 - peak; 12 - wide-mesh screen; 13 - Connecting pipe for air inlet. I - SW feed; II - air inlet; W - steam inlet; IV- synthesis gas combustion products outlet; V- synthesis gas output; VI -ash removal.

To trap the entrained particles of fused alumina and to return them back to the bed, the cyclones (2) and (3) are installed and the mechanical filters (4) and (7) are provided. The entrained particles of fused alumina are returned to the bed as the SW are fed into the lock feeder.

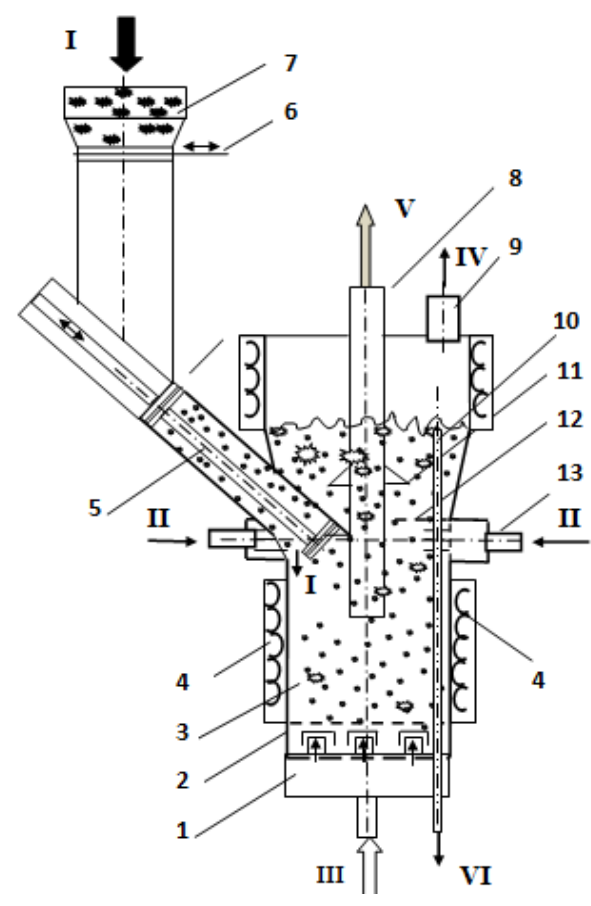

Figure 2: Gasifier system for auto thermal steam gasification of domestic solid wastes (SW). 
Synthesis gas at the outlet of the gasifier (see Fig. 1) is cooled down in the heat exchanger (5), is purified in the scrubber (6), is heated in the heater (8), and is fed into the anode channel of the electrochemical generator. Thermal power of the gases effluent from the ECG is used in the boiler-utilizer (10) to produce steam and to heat air. The combustion productsgenerated power underused in the boiler-utilizer is used in the network heater (12). The combustion products-generated power underused in the gasifier is used in the heater (9) to heat water for household purposes. The synthesis gas is cleaned off the sulfur dioxide using alkali and off hydrogen sulfide using sodium carbonate in the scrubber (6) [8] and using an activated carbon filter. The synthesis gas is heated up to $750^{\circ} \mathrm{C}$ using the heater (8) working on the synthesis gas combustibles. The electrochemical generator is based on the SOFC (10); and the boiler-utilizer (11) is designed for heating up the cathode air, the air for gasifier, and for producing steam for the gasifier. The network heater (12) is designed for heating water for household needs.

\section{GASIFIER PROCESSES SIMULATION}

For steam gasification, the SW of the following composition are used (percent by mass): $\mathrm{C}^{\mathrm{r}}$ (17.4); $\mathrm{H}^{\mathrm{r}}(0.88) ; \mathrm{O}^{\mathrm{r}}(13.85) ; \mathrm{N}^{\mathrm{r}}(0.55) ; \mathrm{S}^{\mathrm{r}}(0.11) ; \mathrm{A}^{\mathrm{r}}(31.9) ; \mathrm{W}^{\mathrm{r}}$ (33.95). The $\mathrm{SW}$ combustion heat is $Q^{\mathrm{p}}=5,000 \mathrm{~kJ} / \mathrm{kg}$.

In the reaction vessel, a reaction of carbon (SW) with steam is carried out at a molar ratio of carbon to water as $\mathrm{C}: \mathrm{H}_{2} \mathrm{O}=1: 1$ according to the stoichiometric equation

$$
\mathrm{C}+\mathrm{H}_{2} \mathrm{O}=0.88 \mathrm{H}_{2}+0.88 \mathrm{CO}+0.09 \mathrm{CO}_{2}+0.06 \mathrm{H}_{2} \mathrm{O}+0.0293 \mathrm{CH}_{4} \text {, }
$$

with the endothermal effect $q_{x 2}=2,900 \mathrm{~kJ} / \mathrm{kg}$ (of synthesis gas). The synthesis gas composition is (percent by volume): $\mathrm{H}_{2}$ (45.378); $\mathrm{CO}$ (45.378); $\mathrm{CO}_{2}$ (4.64); $\mathrm{H}_{2} \mathrm{O}$ (3.094); $\mathrm{CH}_{4}(1.51)$.

True mass isobaric specific heat capacity of synthesis gas is $\mathrm{C}_{\mathrm{SG}}=2.19 \mathrm{~kJ} /(\mathrm{K} \mathrm{kg}$ of synthesis gas). In the combustion chamber, a reaction of partial oxidation of the synthesis gas is carried out, with the air ratio of 1.2 according to the stoichiometric equation

$$
0.88 \mathrm{H}_{2}+0.88 \mathrm{CO}+0.09 \mathrm{CO}_{2}+0.06 \mathrm{H}_{2} \mathrm{O}+0.0293 \mathrm{CH}_{4}+1.2\left(\mathrm{O}_{2}+3.76 \mathrm{~N}_{2}\right)=\mathrm{H}_{2} \mathrm{O}+\mathrm{CO}_{2}+0.2 \mathrm{O}_{2}+4.512 \mathrm{~N}_{2} .
$$

The combustion heat of wet synthesis gas is $q_{x 1}=-16,352 \mathrm{~kJ} /(\mathrm{kg}$ of synthesis gas). The synthesis gas combustion products are of the following composition (percent by volume): $\mathrm{H}_{2} \mathrm{O}$ (14.9); $\mathrm{CO}_{2}$ (14.9); $\mathrm{O}_{2}(2.97) ; \mathrm{N}_{2}$ (67.23). The true mass isobaric specific heat capacity of the combustion products is $C_{\mathrm{c}}=10.42 \mathrm{~kJ} /(\mathrm{K} \mathrm{kg}$ of synthesis gas).

To produce electric power in the ECG at a HPP of $Q_{e}=100 \mathrm{~kW}$, production of synthesis gas would be required in a gasifier with a combustion heat of $q_{x 1}=16.352 \mathrm{~kJ} / \mathrm{kg}$ at a total efficiency of $\eta=0.4(40 \%)$ as taken from [9], [10]:

$$
B_{S G}=Q_{e} / q_{x 1} \cdot \eta=100 /(16.352 \cdot 0.4)=15.29 \cdot 10^{-3} \mathrm{~kg} / \mathrm{s} .
$$

\subsection{Gasifier thermal balance equation}

The combustion heat of the part of synthesis gas $(1-x) \cdot q_{x 1}\left(1-\sum_{3}^{6} q_{i}\right)$ introduced with dry SW q7, moisture q8, air q9, and steam q10 $\left(\sum_{7}^{10} q_{i}\right)$, is spent for carrying out the endothermal reaction producing a fraction $\mathrm{x}$ of the synthesis gas through the $\mathrm{SW}$ carbon steam reforming $x \cdot q_{x 2}$, for heating the reaction products $x \cdot C_{S G} \cdot t$, for heating the 
combustion products of the part of the synthesis gas $(1-x) \cdot C_{c} \cdot t$, and for heating, evaporating, and superheating the steam from the wet SW $q_{11}$.

$$
(1-x) \cdot q_{x 1}\left(1-\sum_{3}^{6} q_{i}\right)+\sum_{7}^{10} q_{i}=x \cdot q_{x 2} B_{S G}+x \cdot C_{S G} \cdot t+(1-x) \cdot C_{\mathrm{c}} \cdot t+q_{11},
$$

where $\sum_{3}^{6} q_{i}=q_{3}+q_{4}+q_{5}+q_{6}$ is the sum of heat losses in the gasifier due to chemical and/or mechanical under burning, losses into the environment through the thermal insulation and with the ashes, $\mathrm{kJ} / \mathrm{kJ}$.

where

$$
\begin{gathered}
\sum_{3}^{6} q_{i}=0.2 \text { (assumed); } \\
\sum_{7}^{10} q_{i}=q_{7}+q_{8}+q_{9}+q_{10},
\end{gathered}
$$

$$
q_{7}=\left(12 C_{d s w} t_{l}\right) /\left(C^{r} 30\right)==(12 \cdot 2.5 \cdot 20) /(0.174 \cdot 30)=115 \mathrm{~kJ} / \mathrm{kg} .
$$

12 and 30 are the molecular mass of carbon and synthesis gas in eqn (1), $C_{\mathrm{SW}}$ is the specific heat capacity of SW, $\mathrm{t}_{1}$ is temperature $20^{\circ} \mathrm{C}, \mathrm{C}^{\mathrm{r}}$ is relative carbon content, $\mathrm{kg} / \mathrm{kg}$ in $\mathrm{SW}$ (per working mass);

$$
\left.q_{8}=\left(12 W^{r} 4.19 t_{l}\right) /\left(C^{r} 30\right)==(0.3395 \cdot 12 \cdot 4.19 \cdot 20) /(0.174 \cdot 30)=65 \mathrm{~kJ} / \mathrm{kg}\right),
$$

where $W^{r}$ is the moisture of $\mathrm{SW}, \mathrm{kg} / \mathrm{kg}$;

$$
q_{9}=\left(164.736 C_{a} t_{1}\right) / 30==(164.736 \cdot 1.024 \cdot 200) / 30=1,098 \mathrm{~kJ} /(\mathrm{kg}),
$$

where 164.736 is the molecular mass of air in the Eq. (2), $t_{1}=200^{\circ} \mathrm{C}$ is the heating temperature of air in the boiler-utilizer (assumed); $C_{a}=1.024 \mathrm{~kJ} / \mathrm{K} \cdot \mathrm{kg}$ is the true isobaric specific heat capacity of air.

$$
q_{10}=\left(18 C_{s} \cdot t_{1}\right) / 30==(18 \cdot 1.977 \cdot 200) / 30=236 \mathrm{~kJ} / \mathrm{kg},
$$

where $C_{s}$ is the true isobaric specific heat capacity of steam.

The sum $\sum_{7}^{10} q_{i}=1,514 \mathrm{~kJ} /(\mathrm{kg}$ of synthesis gas $)$.

$$
q_{11}=\left(W^{r} 12 h_{S S}\right) /\left(C^{r} 30\right)=0.3395 \cdot 12 \cdot 2,874 /(0.174 \cdot 30)=2,243 \mathrm{~kJ} / \mathrm{kg},
$$

where $h_{S S}$ is the superheated steam enthalpy.

From eqn (3) the fraction $x$ is expressed as a function of temperature $t$ in the reaction vessel of the gasifier:

$$
x=\frac{\left.q_{x 1}\left(1-\Sigma_{3}^{6} q_{i}\right)+\Sigma_{7}^{11} q_{i}-C_{S W} \cdot t-q_{11}\right)}{\left.q_{x 1}\left(1-\Sigma_{3}^{6} q_{i}\right)+q_{x 2}+C_{S G^{\prime}} \cdot t-C_{c} \cdot t\right)} .
$$

Substituting into eqn. (4) the temperature $t=1,000^{\circ} \mathrm{C}$ gives the value of the useful fraction of synthesis gas output from the gasifier as $x=0.249$, and the fraction $(1-x)=0.751$ is spent for maintaining the auto thermal gasification of SW steam reforming.

Therefore, to produce $B_{\mathrm{SG}}=15.29 \cdot 10^{-3} \mathrm{~kg} / \mathrm{s}$ of synthesis gas, the feedstock to be put in the gasifier should be as follows:

$\mathrm{SW}-G_{\mathrm{SW}}=141.1 \cdot 10^{-3} \mathrm{~kg} / \mathrm{s}$; 
steam $-G_{\mathrm{H} 2 \mathrm{O}}=36.84 \cdot 10^{-3} \mathrm{~kg} / \mathrm{s}$;

air $-G^{* *}{ }_{\mathrm{a}}=253.23 \cdot 10^{-3} \mathrm{~kg} / \mathrm{s}$.

Total: $431.17 \cdot 10^{-3} \mathrm{~kg} / \mathrm{s}$ (as defined from eqn (1)).

The following must be taken out from the gasifier:

combustion products $G_{\mathrm{c}}=314 \cdot 10^{-3} \mathrm{~kg} / \mathrm{c}$ (as defined from eqn (2));

synthesis gas $B_{\mathrm{SG}}=15.29 \cdot 10^{-3} \mathrm{~kg} / \mathrm{s}$;

ashes $G_{\text {ash }}=45 \cdot 10^{-3} \mathrm{~kg} / \mathrm{s}$;

moisture from the $S W G_{W W}=47.9 \cdot 10^{-3} \mathrm{~kg} / \mathrm{s}$;

oxygen from the $\mathrm{SW} G_{\mathrm{O} 2}=19.54 \cdot 10^{-3} \mathrm{~kg} / \mathrm{s}$;

other products $G_{\mathrm{op}}=4.32 \cdot 10^{-3} \mathrm{~kg} / \mathrm{s}$.

Total: $431.17 \cdot 10^{-3} \mathrm{~kg} / \mathrm{s}$.

3.2 Chemical efficiency of gasifier

$$
\eta_{x}=\left(B_{S G} \cdot q_{x 1}\right) /\left(G_{\mathrm{SW}} \cdot Q_{l}^{p}\right)
$$

To implement this project, a gasifier is required to have the following dimensions. The retort neck diameter is $1 \mathrm{~m}$; the widest retort diameter is $1.62 \mathrm{~m}$; the central pipe (for synthesis gas output) diameter is $0.5 \mathrm{~m}$; the fluidized bed height is $1 \mathrm{~m}$. The calculations were performed for the working velocity of gasification products of $0.5 \mathrm{~m} / \mathrm{s}$ at actual parameters of fused alumina particles size of $0.32 \mathrm{~mm}$.

\subsection{Determining (total) efficiency of ECG}

Fuel cells would normally operate at isobaric-isothermal parameters. The work performed in an isobaric-isothermal process equals the decrease in the Gibbs Free Energy [12]; and the electric power equals the decrease in the Gibbs Free Energy $\Delta G \mathrm{~kJ} / \mathrm{kg}$ of synthesis gas at $1,006 \mathrm{~K}$, multiplied by the synthesis gas consumption rate $B_{\mathrm{SG}}, \mathrm{kg} / \mathrm{s}$ :

$$
Q_{e}=\Delta G \cdot B_{S G} \text {. }
$$

On the other hand, the electric power [8], is

$$
Q_{e}=B_{S G} \cdot q_{x 1} \cdot \eta
$$

Thus, by equating the two expressions, we then get the (total) electric efficiency $\eta=$ $0.391(39.1 \%)$. Because the value of $\eta$ turns out to be less than the previously set value 0.4 , then the resulted electric power has to be somewhat less than $100 \mathrm{~kW}$.

\section{BOILER-UTILIZER}

The boiler-utilizer serves as the site, where hydrogen, fed from the anode channel and underoxidized in the anode, can burn down releasing the power $B_{S G} \cdot\left(1-\varphi_{\mathrm{T}}\right) \cdot \Delta H_{1}^{0}$, and carbon monoxide and methane are burned releasing the power $B_{s g} \cdot \Delta H_{2}^{0}$, reacting with oxygen-depleted air $0.56 \mathrm{O}_{2}+3.76 \mathrm{~N}_{2}$ coming from the cathode channel, according to the following stoichiometric equation:

$$
0.88 \mathrm{CO}+0.09 \mathrm{CO}_{2}+0.94 \mathrm{H}_{2} \mathrm{O}+0.0293 \mathrm{CH}_{4}+\left(0.56 \mathrm{O}_{2}+3.76 \mathrm{~N}_{2}\right)=\mathrm{CO}_{2}+\mathrm{H}_{2} \mathrm{O}+3.76 \mathrm{~N}_{2} \text {. }
$$


The exothermic effect of this reaction is $\Delta H_{2}^{0}=9,192, \mathrm{~kJ} / \mathrm{kg}$ of synthesis gas.

The numbers included in eqns (1)-(7) values are given in Table 1.

\subsection{Boiler-utilizer power budget}

The power $B_{s g}^{*} \cdot \mathrm{C}_{\mathrm{sg}}^{*} \cdot t_{3}^{*}$ coming in with the products from the anode channel, the power $G_{a}$. $\mathrm{C}_{a}^{* *} \cdot t_{2}$ fed with the air from the cathode channel, the power $B_{s g} \cdot\left(1-\varphi_{\mathrm{T}}\right) \cdot \Delta H_{1}^{0}$ released as a result of oxidation of hydrogen unoxidized in the anode, the power $B_{s g} \cdot \Delta H_{2}^{0}$ resulted from oxidation of carbon monoxide and methane coming from the anode channel, the power $G_{a} \cdot \mathrm{C}_{a} \cdot t_{a}$ resulted from the air fed into the cathode channel, the power $\mathrm{C}_{a} \cdot G_{a}^{* *} \cdot t_{a}$, from the air for gasifier, and the power $G_{H_{2 O} O} \cdot h_{e \kappa}$ of the feed water for the gasifier, - all is spent for generating steam for the gasifier $G_{H 2 O} \cdot h_{\text {пा }}$, for heating the cathode air $G_{a} \cdot \mathrm{C}_{a}^{* *} \cdot t_{2}$, for heating the air for the gasifier $G_{a}^{* *} \cdot \mathrm{C}_{a}^{* * *} \cdot t_{1}$ and for heating the gasses effluent from the $\mathrm{BU} G_{e g} \cdot \mathrm{C}_{e g} \cdot t_{e g}$. The value of $\varphi_{\mathrm{T}}$ obtained previously in [11]-[13].

$$
\begin{gathered}
B_{s g}^{*} \mathrm{C}_{s g}^{*} t_{3}^{*}+G_{a}^{*} \mathrm{C}_{a}^{*} t_{2}^{*}+B_{s g}\left(1-\varphi_{\mathrm{T}}\right) \Delta H_{1}^{0}+B_{s g} \Delta H_{2}^{0}++G_{a} \mathrm{C}_{a} t_{a}+\mathrm{C}_{a} G_{a}^{* *} t_{a}+G_{H 2 O} h_{\text {эк }}= \\
=G_{H 2 O} h_{\Pi \Pi}+G_{a} \mathrm{C}_{a}^{* *} t_{2}+G_{a}^{* *} \mathrm{C}_{a}^{* *} t_{1}+G_{e g} \mathrm{C}_{e g} t_{e g} .
\end{gathered}
$$

From eqn (9), the temperature of gasses effluent from the BU can be written down:

$$
\begin{gathered}
t_{e g}=\left[B_{s g}^{*} C_{s g}^{*} t_{3}^{*}+G_{a}^{*} C_{a}^{*} t_{2}+B_{s g}\left(1-\varphi_{\mathrm{T}}\right) \Delta H_{1}^{0}+B_{s g} \Delta H_{2}^{0}\right. \\
-G_{a}\left(G_{a}^{* *} t_{2}-C_{a} t_{a}\right)- \\
\left.-G_{a}^{* *}\left(C_{a}^{* * *} t_{1}-C_{a} t_{a}\right)-G_{H 2 O}\left(h_{s s}-h_{e \kappa}\right)\right] /\left(G_{e g} C_{e g}\right) .
\end{gathered}
$$

Substituting the values from Table 2 into eqn (9) yields the value $t_{e g}=630^{\circ} \mathrm{C}$. Power out of the $\mathrm{BU}$ is

$$
Q_{2}=G_{e g} \cdot \mathrm{C}_{e g} \cdot t_{e g} \cdot
$$

Power of the network heater $\left(t_{e g}^{*}=120^{\circ} \mathrm{C}\right.$ into the flue $)$

$$
Q_{N H}=G_{e g} \cdot C_{e g} \cdot\left(t_{e g}-t_{e g}^{*}\right) .
$$

The specific ECG heat loss with effluent gases is

$$
q_{2}=Q_{2} /\left(B_{s g} \cdot q_{x 1}\right) \text {. }
$$

The specific ECG heat loss into the environment is

$$
q_{5}=1-\eta-q_{2}=0.32
$$

The chemical underburning is assumed to be $q_{3}=0$.

The synthesis gas heater power is (position 8 in Fig.1)

$$
Q_{s g}=G_{s g}\left(C_{s g} \cdot t_{3}-\mathrm{C}_{s g}^{* *} \cdot t_{l}\right)
$$




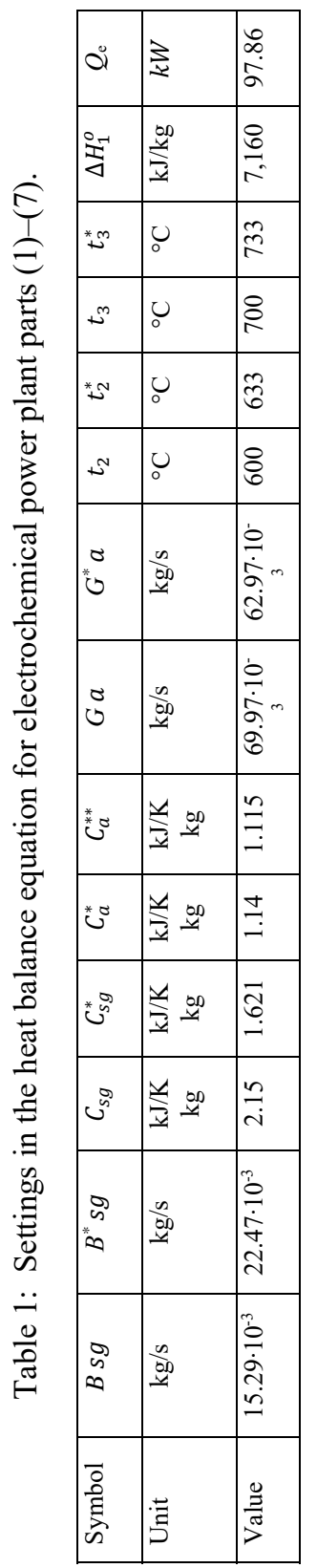

\begin{tabular}{|c|c|c|}
\hline$\frac{T^{2}}{4}$ & 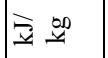 & $\bar{\sigma} \sigma$ \\
\hline$\frac{y^{2}}{4}$ & $\nexists \underset{x}{\infty}$ & $=8$ \\
\hline 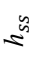 & 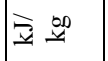 & $\underset{i}{\infty}$ \\
\hline$\Xi$ & 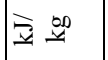 & $\because 2$ \\
\hline$\stackrel{n}{\infty}$ & 0 & $\cong n$ \\
\hline$\infty$ & 0 & i o \\
\hline$\stackrel{\sim}{\sim}$ & 0 & $8 \mathrm{~m}$ \\
\hline$\sim$ & 0 & 8 \\
\hline$\approx$ & 0 & ๙ิ \\
\hline 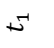 & $\circ 0$ & iి \\
\hline$\omega^{\circ}$ & $\frac{n}{200}$ & $\begin{array}{lll}\pi & 0 \\
\infty & 0 & 0\end{array}$ \\
\hline 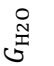 & $\frac{n}{200}$ & $\stackrel{\infty}{\dot{\infty}}+?$ \\
\hline 婄 & $\frac{n}{800}$ & $\approx \tilde{\pi} \approx 0$ \\
\hline ت & $\frac{n}{b 0}$ & $\hat{\mathrm{i}} \sim \hat{\theta}$ \\
\hline E & $\begin{array}{ll}300 \\
1\end{array}$ & 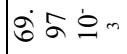 \\
\hline 豙 & 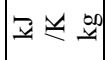 & $-\approx m$ \\
\hline 粰 & 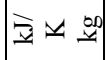 & $\stackrel{-}{-} \underset{\sim}{\Delta}$ \\
\hline 晎 & $\pm \simeq$ & $\because \because$ \\
\hline$v$ & $\Xi \simeq$ & Oㄹ \\
\hline * & 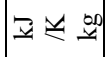 & $-\dot{I}$ \\
\hline * & $\approx \simeq$ & $-\sigma^{-}$ \\
\hline * o & $\begin{array}{ll}00 & 0 \\
-1 & n\end{array}$ & 추으. \\
\hline$\infty 0$ & $\frac{20}{2}$ in & $\ddot{2}$ ㅊ응 \\
\hline 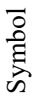 & 节 & $\frac{\cong}{\stackrel{\Xi}{\pi}}$ \\
\hline
\end{tabular}


The temperature of combustion products behind the synthesis gas heater is

$$
t_{\mathrm{x}}=t-Q_{s g} /\left(G_{c} \cdot C_{c}\right) \text {. }
$$

The power of utilizer (position 12 in Fig. 1) of combustion products heat behind the synthesis gas heater is

The fuel utilization is

$$
Q_{N H}^{*}=G_{c} \cdot C_{c}\left(t_{x}-t_{e g}^{*}\right)
$$

$$
\eta_{\mathrm{u}}=\left(Q_{e}+Q_{N H}+Q_{N H}^{*}\right) /\left(G_{d s w} \cdot Q_{l}^{P}\right)
$$

\section{SOFC-BASED MINI-HPP PERFORMANCE CHARACTERISTICS}

The capability of dividing the SW consumed for electric power or heat generation. Absolute SW consumption for generation of electric energy

$$
G_{l d s w}=Q_{e} \cdot 1 \cdot 3,600 /\left(Q_{l}^{\mathrm{p}} \cdot \eta_{u}\right)
$$

Specific SW consumption for generation of electric energy

$$
b_{e}=G_{h d s w} / Q_{e}
$$

Absolute SW consumption for heat generation

$$
G_{h d s w}=\left[\left(Q_{N H}+Q_{N H}^{*}\right) \cdot 1 \cdot 3,600\right] /\left(Q_{l}^{\mathrm{p}} \cdot \eta_{u}\right) .
$$

Specific SW consumption for heat generation

$$
b_{h}=G_{h d s w} \cdot 10^{6} /\left[\left(Q_{N H}+Q_{N H}^{*}\right) \cdot 1 \cdot 3,600\right] .
$$

The difference between SW consumption to be fed into the gasifier and the one used for generation of electric and thermal energies is

$$
\begin{gathered}
\Delta G_{d s w}=G_{d s w}-\left(G_{l d s w}+G_{h d s w}\right) / 3,600 \\
\left(\Delta G_{d s w} \text {-is zero }\right) .
\end{gathered}
$$

The calculation results are presented in Table 3 .

\section{CONCLUSIONS}

1. A calculation research effort has been made to support the application of an auto thermal fused-alumina fluidized-bed gasifier for synthesis gas generation through the steam gasification of domestic solid wastes, which is to be used for SOFC-based electrochemical generator operation.

2. The calculations have demonstrated the following: the temperature in the reaction vessel of the gasifier is at $1,000^{\circ} \mathrm{C}$, the synthesis gas output is $55 \mathrm{~m} 3 / \mathrm{h}$, the chemical efficiency is $35.4 \%$, and the synthesis gas combustion heat is $1.6352 \mathrm{~kJ} / \mathrm{kg}$ of synthesis gas.

3. The ECG electric power is $97.86 \mathrm{~kW}$, the ECG efficiency is $39.1 \%$, the temperature of gases effluent from the boiler-utilizer is at $630^{\circ} \mathrm{C}$. 


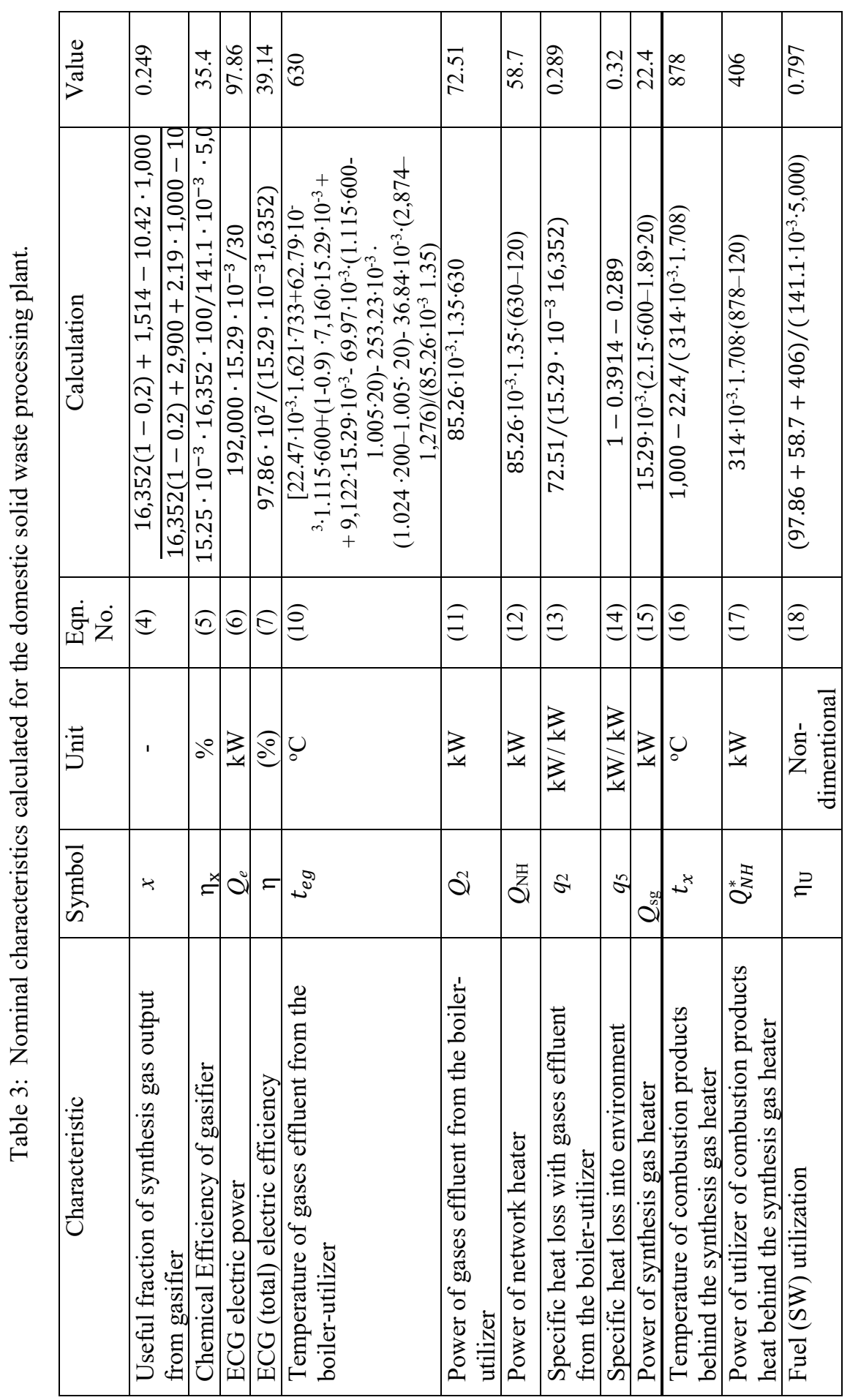




\begin{tabular}{|c|c|c|c|c|c|}
\hline$\frac{0}{\frac{0}{\pi}}$ & 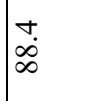 & $\hat{0} \frac{n}{0}$ & 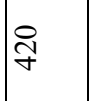 & 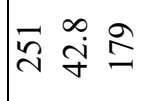 & 0 \\
\hline 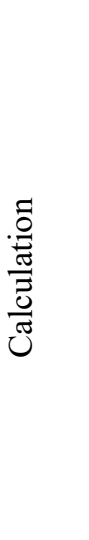 & 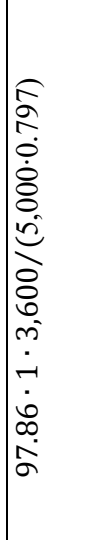 & 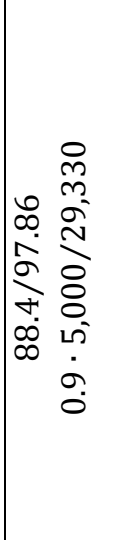 & 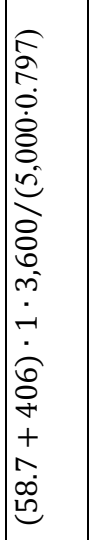 & 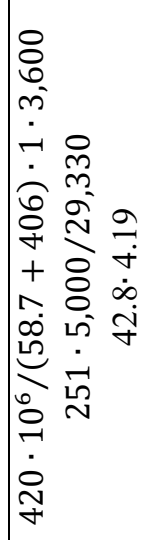 & 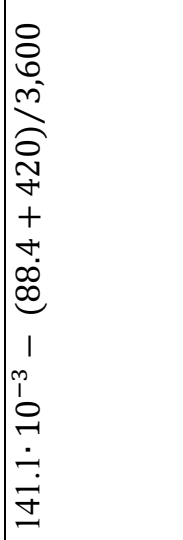 \\
\hline ت્ઞ் & $\stackrel{\curvearrowright}{\varrho}$ & 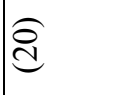 & $\widehat{\overparen{d}}$ & ป & $\overparen{\widehat{d}}$ \\
\hline 志 & 预 & 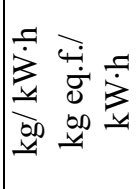 & 点 & 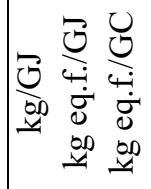 & $\frac{\infty}{000}$ \\
\hline $\begin{array}{l}\text { ठ } \\
\text { है } \\
\text { क }\end{array}$ & $\frac{3}{3}$ & $0^{\circ}$ & 勇 & 5 & 㤐 \\
\hline 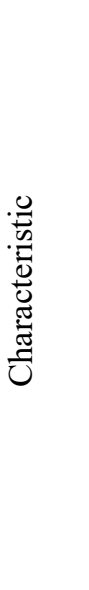 & 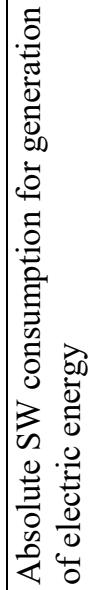 & 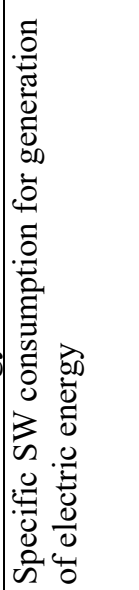 & 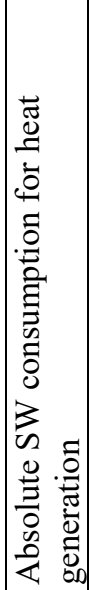 & 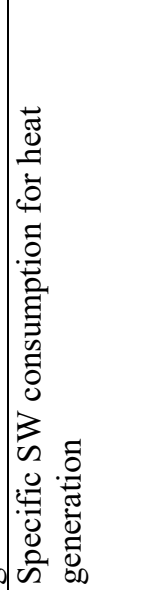 & 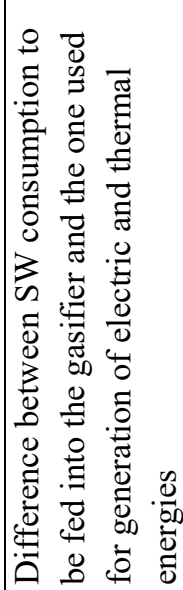 \\
\hline
\end{tabular}


4. The specific SW consumption to produce electric energy is $0.9 \mathrm{~kg} / \mathrm{kWh}(0.153 \mathrm{~kg}$ eq.f. $/ \mathrm{kWh}$ ), and to produce thermal energy is $251 \mathrm{~kg} / \mathrm{GJ}$ (43.8 kg eq.f./GJ;179 kg eq.f./GC).

5. Theorized the possibility of solid waste into electrical and thermal energy with full efficiency more than $79 \%$.

\section{ACKNOWLEDGEMENT}

This article should be prepared with the financial support of the Government of the Russian Federation (contract No. 02. And 03.21.0006).

\section{REFERENCES}

[1] Gómez, S.Y. \& Hotza, D., Current developments in reversible solid oxide fuel cells// Renewable and Sustainable Energy Reviews, 61, pp. 155-174, 2016.

[2] Halinen, M., Thomann, O. \& Kiviaho, J., Effect of anode off- gas recycling on reforming of natural gas for solid oxide fuel cell systems//Fuel cells 12, 5, pp. 754 760, 2012.

[3] Rayner, A.J. \& Briggs, J., Tremback, R., Clemmer, R.M.C., Design of an organic waste power plant coupling anaerobic digestion and solid oxide fuel cell technologies.

Renewable and Sustainable Energy Reviews, 71, pp. 563-571, 2017.

[4] Rokni, M., Thermodynamic analyses of municipal solid waste gasification plant integrated with solid oxide fuel cell and Stirling hybrid system. International Journal of Hydrogen Energy, 40(24), pp. 7855-7869, 2015.

[5] Bellomare, F. \& Rokni, M., Integration of a municipal solid waste gasification plant with solid oxide fuel cell and gas turbine, Renewable Energy, 55, , pp. 490-500, 2013.

[6] Peters, R., Deja, R., Blum, L., Pennanen, J., Kiviaho, J. \& Hakala, T., Analysis of solid oxide fuel cell system concepts with anode recycling, International Journal of Hydrogen Energy. 38. pp. 6809-6820, 2013.

[7] Osipov, P.V., Chernyavskiy, N.V. \& Ryzhkov, A.F., The study of combustion nature of volchansk brown coal in fluidized bed. Thermal physics and thermal power: collection of scientific articles, Magnitogorsk MAGU, pp. 96-99, (in Russ.), 2010.

[8] Hoffman, E.J., Coal conversion, Energoatomizdat, Moscow, p. 328, (in Russ.), 1983.

[9] Korovin, N.V., Fuel cells and electrochemical power plants, 2005, MEI Publishing, Moscow, [in Russ.)].

[10] Sobyanin, V.A., High-temperature solid-oxide fuel cells and conversion of methane, Russ J General Chem, XLVII(6), pp. 2-70, (in Russ.), 2003.

[11] Baskakov, A.P., Volkova \& Yu.V., Physicochemical principles of thermal processes, Teplotekhnick. Moscow, pp. 173, (in Russ.), 2013.

[12] Munts, V.A. et al., Studying the characteristics of a $5 \mathrm{~kW}$ power installation on solidoxide fuel cells with steam reforming of natural gas, Therm Eng Pub, 62(11), p. 779784, (in Russ.), 2015.

[13] Baskakov, A.P., Volkova, Yu.V. \& Plotnikov, N.S., Optimum chemical regeneration of the gases burnt in solid oxide fuel cells. Journal of Engineering Physics and Thermophysics, 87(4), pp. 763-778, 2014. 